\title{
TAPISERIE Z WYPRAWY ŚLUBNEJ KRÓLOWEJ BONY SFORZY D’ARAGONA
}

Królowej Bonie Sforzy d'Aragona, która przybyła do Rzeczypospolitej z dalekiego Bari, poświęcono wiele polskich i obcych, w tym zwłaszcza włoskich, prac naukowych, popularnonaukowych i beletrystycznych (HennelBernasikowa 271; Bender, „Bona Sforza” 34). Urodziwa, świetnie wykształcona, obdarzona silnym charakterem i żywym temperamentem, przywiozła z sobą także wspaniały posag, godny jedynej pozostałej przy życiu córki księżnej Izabelli d'Aragona, opisany szczegółowo przez Giuliano Passero, „setaiolo napoletano" - neapolitańskiego wytwórcę lub handlarza tkaninami jedwabnymi (Bender, „Bona Sforza” 38). Wśród wielkiej liczby wspaniałych przedmiotów, ubiorów i tkanin, które były uroczyście prezentowane gościom weselnym 6 grudnia 1517 r., po zaślubinach per procura w Castel Capuano w Neapolu, znalazły się tapiserie - „panni di razza” (Passero 256), najbardziej kosztowne ówcześnie tkaniny dekoracyjne, służące najczęściej do dekoracji ścian, na które mogli sobie pozwolić jedynie najwyżsi dostojnicy świeccy i kościelni.

Niestety bardzo niewiele wiemy na temat tego rodzaju tkanin w zbiorach polskich przed przyjazdem Bony, czyli do 1518 r. Istnieje jednak kilka wzmianek źródłowych, które wskazują, że importowane tapiserie jako dary znalazły się w XV wieku w zbiorach katedry gnieźnieńskiej i krakowskiej, kapituły włocławskiej oraz w skarbcu książąt mazowieckich (Bender, Tapiserie 82-83). Miał je także Zygmunt I Stary w swoim zamku, gdy przybyła doń Bona Sforza, o czym w dalszej części tekstu.

Dr hab. Agnieszka Bender - Katolicki Uniwersytet Lubelski Jana Pawła II, Wydział Nauk Humanistycznych, Instytut Nauk o Sztuce, Katedra Historii Sztuki Średniowiecznej i Nowożytnej; adres do korespondencji: Al. Racławickie 14, 20-950 Lublin; e-mail: agbender@kul.pl; ORCID: https://orcid.org/0000-0002-0432-7436. 
Celem niniejszego artykułu jest uzupełnienie dotychczasowej wiedzy i uściślenie niektórych znanych informacji na temat przywiezionych z Italii przez królową Bonę tapiserii. Pogłębienie wiedzy na ich temat stało się możliwe dzięki dotarciu do kilku wcześniej nieznanych polskiej literaturze przedmiotu źródeł oraz opracowań pióra włoskich autorów.

$\mathrm{Na}$ wstępie należy zauważyć, że omawianemu problemowi do tej pory został poświęcony tylko jeden, dość zresztą krótki artykuł, autorstwa uznanej badaczki tapiserii Marii Hennel-Bernasikowej, który został zamieszczony w pracy zbiorowej, przygotowanej przez polskich i włoskich badaczy, a ukazał się dwadzieścia lat temu (Hennel-Bernasikowa passim). W tym kontekście trzeba dodać, że bardzo ogólne informacje o wspomnianych tkaninach pojawiają się w większości prac dotyczących Bony.

Zasadne wydaje się przytoczenie na początku niniejszych rozważań fragmentu wspomnianego opisu neapolitańskich uroczystości ślubnych Bony, autorstwa Giuliano Passero, w którym wymieniono tapiserie:

Panni di razza. Otto panni grandi di Fiandana [Fiandra] con seta assai, con le sette opere della misericordia, et quatro portieri per due camere costano mille docati d'oro. (Passero 256)

Sztuki tapiserii. Osiem sztuk dużych z Flandrii, z dużą ilością jedwabiu, z przedstawieniem siedmiu aktów miłosierdzia, i cztery portiery do dwóch pokoi, kosztują tysiąc dukatów w złocie. (Przekład A.B.)

Ten krótki tekst można spróbować nieco szerzej zinterpretować. Na wstępie podkreślono w nim spore rozmiary tkanin, co często oczywiście przekładało się na ich cenę. Seria ośmiu tapiserii też nie należała do małych. Już te elementy opisu wskazują, że były to niewątpliwie bardzo kosztowne tkaniny. Dalej zaznaczono również, że tapiserie wykonano we Flandrii, która w tym czasie słynęła z najwyższej klasy wyrobów. Jak zauważa Maria Hennel-Bernasikowa, omawiane tapiserie, które zapewne wykonano pod koniec XV lub w pierwszym piętnastoleciu XVI wieku, powstały być może w Tournai lub stającej się coraz bardziej renomowanym ośrodkiem wyrobu tych luksusowych tkanin Brukseli (Hennel-Bernasikowa 271). Informacja o „dużej ilości jedwabiu", który dodano, i to obficie, do wełnianej przędzy, jest kolejnym elementem wyróżniającym tę serię tapiserii, świadczącym o jej wysokiej jakości, delikatnym rysunku i niemałej cenie. Nie posiadała ona wprawdzie, jak należy mniemać, nici złotych lub srebrnych, bo w przeciwnym razie autor opisu na pewno by o tym fakcie wspomniał. 
Kolejna ważna informacja zawarta w omawianym tekście mówi o temacie przedstawienia, którym są Akty lub Uczynki miłosierdzia. Ten temat, dotyczący zapewne uczynków miłosierdzia względem ciała (?), już w średniowieczu pojawia się w cyklu siedmiu scen, rodzajów jałmużny, często łączonym z Sądem Ostatecznym. Są to następujące uczynki: 1. Nakarmienie głodnych; 2. Napojenie spragnionych; 3. Przyodzianie nagich; 4. Przyjmowanie do domu podróżnych; 5. Pocieszanie więźniów; 6. Odwiedzanie chorych; 7. Grzebanie umarłych (Seremak 1284-1285). Od XII wieku owe sceny występowały w iluminacjach manuskryptów, dekoracji portali, witraży czy też jako malowidła na ścianach szpitali i świątyń („,The Seven Works of Mercy”, dostęp 5.11.2020). Później podejmowali je malarze obrazów tablicowych i rytownicy (Hennel-Bernasikowa 271; van Bühren 66; Botana passim). Przesłanie dzieł miało zachęcać wiernych do jałmużny. Prace o tej tematyce można odnaleźć w różnych krajach, m.in. we Włoszech, w Wielkiej Brytanii, w Niemczech, w Polsce oraz w Belgii i w Holandii.

W zbiorach europejskich po dziś dzień zachowały się przynajmniej cztery serie, nie wszystkie kompletne, flamandzkich obrazów olejnych na desce, powstałych w końcu XIV lub na początku XVI wieku, z przedstawieniem Uczynków miłosierdzia, które mogły służyć jako wzór do wykonania tapiserii. Z pierwszej z nich, autorstwa Mistrza widoku św. Gduli, czynnego w Brukseli w latach 1470-1500, przetrwały do naszych czasów zaledwie dwa obrazy o wymiarach $63,5 \times 41,5 \mathrm{~cm}$. Jeden z nich, ukazujący Przyodziewanie nagich, znajduje się w Muzeum Thyssen-Bornemisza w Madrycie („Meester van Sint Goedele", dostęp 5.11.2020). Drugi, przedstawiający Pocieszanie więźniów, przechowuje paryskie Musée de Cluny. Powstanie tych prac jest datowane na około $1470 \mathrm{r}$.

Kolejny cykl obrazujący Uczynki miłosierdzia został namalowany między 1490 a 1500 r. przez nieznanego artystę i był przeznaczony do Aalmozenierskamer (siedziby bractwa miłosierdzia?) w Antwerpii, obecnie zaś jest eksponowany w Maagdalenhuismuseum w tym mieście (van Bühren 68). Wymiary obrazu to $115 \times 125 \mathrm{~cm}$. Sceny ukazujące Siedem uczynków miłosierdzia uzupełniono w tej pracy scenami przedstawiającymi Siedem grzechów głównych i przedstawieniem Sadu Ostatecznego.

Najsławniejszym dziełem malarskim prezentującym Uczynki miłosierdzia, powstałym na początku XVI wieku, jest cykl siedmiu obrazów autorstwa Mistrza z Alkmaaru, anonimowego malarza niderlandzkiego, którego utożsamia się ostatnio z Pieterem Gerritszem z Haarlemu (zm. 1504) lub z Cornelisem Buysem Starszym (czynny 1490-1524). Seria malowideł, o raczej 
niewielkich rozmiarach - każde mierzy $101 \times 54 \mathrm{~cm}$, zamówiona w $1504 \mathrm{r}$. przez Bractwo Ducha Świętego dla parafialnego kościoła Sint-Laurentskerk w Alkmaar, obecnie jest eksponowana w Rijksmuseum w Amsterdamie (Genaille 134; Meijer 24, 33-35; van Bühren 69).

Czwarty obraz, którego historia nie jest tak dobrze rozpoznana jak poprzednio wymienionych, składa się z ośmiu scen - siedem ukazuje Uczynki miłosierdzia, ósma przedstawia klęczących donatorów, parę małżeńską z trzema córkami. Obraz autorstwa Meester van de Levensbron ma wymiary $65 \times 110 \mathrm{~cm}$. Wiadomo, że zmieniał wielokrotnie prywatnych właścicieli i od lat siedemdziesiątych XX wieku znalazł się w zbiorach Rijksmuseum Twenthe w Enschede („Meester van de Levensbron”, dostęp 5.11.2020).

O ile istotnie któryś z powyższych cykli siedmiu uczynków stał się wzorcem do wykonania kartonów do serii tapiserii Bony, to wymiary poszczególnych scen musiały zostać znacznie powiększone oraz musiano dodać jeszcze jedną, ósmą scenę, która ukazywała najpewniej Są Ostateczny. Należy nadmienić, że najważniejszym flamandzkim przedstawieniom Sądu Ostatecznego nie towarzyszyły sceny z Uczynkami milosierdzia, czego przykładem są dzieła m.in. Jana van Eycka, Petrusa Christusa czy gdański tryptyk Hansa Memlinga (Genaille 176-179).

Niestety, mimo usilnych poszukiwań Marii Hennel-Bernasikowej oraz autorki niniejszego artykułu, nie udało się dotąd znaleźć żadnych informacji na temat serii tapiserii z Uczynkami miłosierdzia. Można jednak przypuszczać, że pod względem formalnym i stylistycznym sceny ukazane na tapiseriach musiały być mocno zbliżone do tych przedstawionych na wymienionych, powstałych wówczas flamandzkich obrazach tablicowych.

Maria Hennel-Bernasikowa $\mathrm{w}$ artykule o tapiseriach Bony zadaje retoryczne pytanie, czy seria tkanin z Uczynkami miłosierdzia była może nawiązaniem do jej imienia - Bona, czyli „dobra” (Hennel-Bernasikowa 272). Po latach od powstania tegoż tekstu wciąż trudno odpowiedzieć jednoznacznie na to pytanie. W świetle jednak dostępnego materiału porównawczego wygląda raczej na to, że dzieła sztuki obrazujące omawiany temat były zamawiane przez instytucje kościelne, kościoły lub coraz bardziej rozpowszechniające się wówczas bractwa miłosierdzia. Warto w tym miejscu dodać jeszcze wiadomość podaną przez Francesco Malaguzzi Valeri, że w XV i XVI wieku istniał dosyć rozpowszechniony zwyczaj wzajemnego pożyczania sobie tapiserii przez dwory i instytucje kościelne (Malaguzzi Valeri 14). Jak zatem można sądzić, musiał też funkcjonować dobry przepływ informacji na temat, kto i co w danym czasie posiadał. Izabella Aragońska, 
która od dziecka obracała się wśród elit dworskich, nie raz widziała serie tapiserii $\mathrm{w}$ pałacowych wnętrzach, świadczące o najwyższym statusie społecznym i materialnym, które wręcz stawały się ich wyznacznikiem, miała niewątpliwie głęboką świadomość, że tego rodzaju tkaniny powinny znaleźć się w ślubnej wyprawie przyszłej królowej. Warto dodać, że w czasie jej ślubu z Gian Galeazzo Sforzą we wnętrzach odnotowano wśród dekoracyjnych tkanin także tapiserie (Malaguzzi Valeri 14; Passera 320). Wygląda zatem na to, że matka Bony, która przygotowywała wyprawę córki, nie zamówiła sama specjalnie tej serii z przedstawieniami Uczynków miłosierdzia. Raczej nabyła gotowe tkaniny, być może wcześniej przeznaczone dla jakiegoś kościoła lub bractwa, które w ostatniej chwili wycofało się z zakupu lub też je sprzedało, aby zyskać fundusze na inne cele. Bona chyba była świadoma faktu, że tapiserie nie miały świeckiego przeznaczenia, co zostanie omówione w dalszej części artykułu.

Wracając do zacytowanego zdania $\mathrm{z}$ opisu posagu Bony, dowiadujemy się $\mathrm{z}$ niego, że w jej wyprawie były jeszcze cztery portiery przeznaczone do dwóch pokoi. Portierami nazywano tkaniny zawieszane na drzwiach, których funkcją była, z jednej strony, dekoracja wnętrza, z drugiej zaś ochrona przed przeciągami i hałasem. $Z$ tych powodów były wykonywane $\mathrm{z}$ różnych grubych tkanin, w tym i tapiserii. Nazwa tej grupy wyrobów wywodzi się z języka łacińskiego - od słowa porta oznaczającego „drzwi”. Ich historia sięga jeszcze czasów antycznych, ale więcej wzmianek na temat portier pojawia się $\mathrm{w}$ Italii $\mathrm{w}$ drugiej połowie $\mathrm{XV}$ wieku. Wówczas to serie portier z tkanin dekorowano już przedstawieniami herbów i postaci, i ten zwyczaj później się utrwali. Dopiero XVI i XVII wiek przyniosą rozwój produkcji portier z tapiserii (Tosi, „Portiera”, dostęp 5.11.2020). W polskich źródłach występują one szczególnie często w późniejszych czasach - w XVII i XVIII wieku (Bender, Tapiserie 63). Wspomniana więc informacja o portierach Bony wydaje się być pierwszą dotyczącą tego rodzaju elementów wyposażenia wnętrz rezydencjonalnych na naszych ziemiach. Niestety w tym przypadku nie podano, gdzie owe portiery były wykonane. Można jedynie sądzić, że mogły to być wyroby włoskie. Na przełomie XV i XVI wieku w Italii działało już kilka ośrodków. Pierwsze wzmianki na temat flandryjskich wytwórców tapiserii na terenie Półwyspu Apenińskiego pochodzą z 1420 r. (Forti Grazzini 133). W drugiej połowie XV wieku, najpierw od 1455 r. w Mediolanie (Malaguzzi Valeri 13-14; Passera 320), a potem od czasów okrutnego Lodovica il Moro Sforzy w Vigevano niedaleko Mediolanu, działały prowadzone przez flandryjskich tkaczy manufaktury tapiserii (Mala- 
guzzi Valeri 13-23; Chruszczyńska i Orlińska-Mianowska 148), które matka Bony musiała dobrze znać, bo w właśnie w Vigevano przypuszczalnie na świat przyszła królowa Polski. Prezentując zagadnienia dotyczące flandryjskich tkaczy we Włoszech w XVI wieku, Nello Forti Grazzini zauważa, że większe serie tapiserii Włosi $\mathrm{w}$ tym czasie importowali z Flandrii, gdyż miejscowe warsztaty wykonywały tkaniny o mniejszych wymiarach (Forti Grazzini 134). Ta opinia może skłaniać do postawienia hipotezy, że omawiane portiery mogły być dziełem jednej z lokalnych manufaktur. Niestety nic nie wiemy na temat wyglądu owych portier, gdyż nie podano, jakie wyobrażenia zdobiły te cztery tkaniny. Sądzić jednak można, że były to herby Bony lub obojga małżonków.

$\mathrm{Na}$ koniec niniejszej próby interpretacji zdania zapisanego przez Giuliano Passero na temat tapiserii Bony należy zastanowić się, czy podana suma 1000 dukatów w złocie za wszystkie tapiserie, to znaczy osiem z Uczynkami miłosierdzia i cztery portiery, była wysoka czy też nie. Maria Hennel-Bernasikowa zauważyła, że „tylko ta jedna pozycja w całym spisie ma podaną pieniężną wartość" (Hennel-Bernasikowa 271). Z tą opinią autorki można się tylko częściowo zgodzić, gdyż we w fragmencie dotyczącym obić ściennych i mebli istotnie jest to jedyna pozycja z zaznaczoną kwotą. W całym jednak spisie Passero w kilku miejscach podaje wartość opisywanych ubiorów czy klejnotów. I tak, kolejno, wartość biżuteryjnych ozdób jednego z polskich ambasadorów kronikarz wycenił na 50000 dukatów (Passero 242); wartość ślubnego ubioru Bony oszacował na 7000 dukatów (Passero 243); dwie najdroższe suknie Bony wycenił - jedną na 2000, drugą na 4000 dukatów (Passero 257). Warto w tym kontekście wspomnieć, że cały posag włoskiej księżniczki był wart 200000 dukatów (Bogucka 47). Dla porównania można dodać, że tylko za jedną tapiserię, z serii dziesięciu, zaprojektowaną przez Rafaela, wykonaną z zastosowaniem nici srebrnych i złotych przez warsztat Pietera van Aelsta III, która została zamówiona w 1515 r. do Kaplicy Sykstyńskiej, zapłacono 1600 lub nawet 2000 dukatów (Campbell 198). Jak zatem widać, kwota 1000 dukatów nie była oczywiście małą, ale też seria tapiserii Bony nie należała do ówcześnie najkosztowniejszych.

Kolejna wzmianka na temat tapiserii Bony znajduje się w wierszowanym utworze pt. Viaggio della Serenissima S. Bona Regina in Polonia autorstwa poety Colantonio Carmignano, który towarzyszył królowej w jej podróży z Bari do Krakowa. W kilku miejscach jego opisów pojawiają się informacje o kosztownych tkaninach. Pierwszy raz, przy opisie wnętrz kajut Bony podczas przeprawy przez morze, wymienia „razzi fini”, czyli tapiserie, które 
wykonano z dużą starannością i bardzo delikatnie, najpewniej z bardzo cienkiej przędzy. Dodaje, że te tapiserie znajdowały się w antykamerze (Carmignano 44). Można przypuszczać, że były to wspomniane wyżej portiery, które cechowały się niewielkimi rozmiarami i które - jak wspomniano - były udekorowane, być może, herbami. Nawet w czasie podróży zatem tego rodzaju luksusowe tkaniny mogły dodawać prestiżu. Jak wiadomo $\mathrm{z}$ różnych źródeł $\mathrm{z}$ tego czasu, tapiserie towarzyszyły ich właścicielom czasem $\mathrm{w}$ trakcie bardzo dalekich wyjazdów, brano je nawet na wyprawy wojenne (Campbell 22-23).

Kolejne wzmianki we włoskim utworze o tapiseriach dotyczą już tkanin, które Carmignano zobaczył na zamku w Krakowie. Pisze on, że „molti belli razzi" - wiele pięknych tapiserii - widział w komnacie na pierwszym piętrze, świeżo urządzonej dla nowej królowej (Carmignano 88). Na drugim piętrze poeta podziwiał też jeden z pokoi, który zdobiły „razzi in seta et oro”, czyli tapiserie wykonane z przędzy jedwabnej, lub raczej z jej obfitym dodatkiem, oraz z dodatkiem nici złotych (Carmignano 88). Te naturalnie należały do najbardziej kosztownych. Kolejne „razzi in seta” - dosłownie tapiserie z jedwabiu, co też należy rozumieć jako obfite dodanie przędzy jedwabnej do wełnianej - poeta widział w kolejnych czterech pokojach (Carmignano 89). Nie można się w tym miejscu zgodzić z opinią Marii Hennel-Bernasikowej, że wszystkie wymienione przez Colantonia Carmignano „określenia [...] tkanin, obecnie [są] trudne do zidentyfikowania. Być może były wśród nich arrasy, lecz nie jest to pewne, bo autor nie wspomina, aby widniały na nich przedstawienia" (Hennel-Bernasikowa 272). Informacje ze słowników włoskich (Ghidoli, „Arazzo”. Enciclopedia Italiana i „Arazzo”. Dizionario italiano, dostęp 5.11.2020) oraz porównanie licznych innych tekstów włoskich z tego czasu umożliwiło autorce niniejszego artykułu stwierdzenie, że Carmignano, podobnie jak inni Włosi z południa, używał wówczas dla określenia tapiserii wspomnianej nazwy „razzi”, uchodzącej za trochę archaiczną w innych regionach (Passero 256; Beatillo, Historia della vita 965; Malaguzzi Valeri 13; „Regione siciliana”, dostęp 5.11.2020).

Wracając do serii z Uczynkami miłosierdzia, należy dodać, że Jost Ludwik Decjusz w opisie wyprawy Bony, prezentowanej już na zamku w Krakowie, wspomina ogólnie o tapiseriach za scenami (Hennel-Bernasikowa 273).

Nie ma informacji, czy i gdzie zawisły przywiezione przez królową tapiserie. Nie wiemy, czy seria oraz portiery ozdobiły wnętrza zamku krakowskiego, czy też może zawisły w innym miejscu. Portiery jako tkaniny niezbyt dużych rozmiarów zapewne łatwo znalazły godne miejsce w którymś z licznych zamkowych pomieszczeń. Czy seria ośmiu dużych flamandzkich tapi- 
serii również ozdobiła ściany nowej rezydencji Włoszki? Trudno jednoznacznie odpowiedzieć na to pytanie. Istnieją informacje sugerujące, że dwa lata później królowa mogła odesłać serię tapiserii do Bari.

Autor kilku prac na temat Bony, Gerardo Cioffari, w dwóch swoich publikacjach, powołując się na informacje z książki Antoniego Beatilla Historia di Bari z 1637 r., podaje, że królowa serię z Uczynkami miłosierdzia miała podarować bazylice Świętego Mikołaja w Barii zaraz po urodzeniu syna, Zygmunta Augusta, czyli w 1520 r. W artykule autor podaje, że wiadomość o tym fakcie znalazł na 206 stronie pracy Beatilla (Cioffari, „Bona Sforza. Aspetti” 102). W wydanej kilkanaście lat później książce Gerardo Cioffari w niemal identyczny sposób formułuje tę informację. W tym jednak przypadku, nie podając odsyłacza, zaznacza ogólnie, że powołuje się na wiadomość pochodzącą od Beatilla (Cioffari, Bona Sforza. Donna 259). Niestety ani na wskazanej stronie, ani w całej wspomnianej książce Antonio Beatillo nie pisze nic o tapiseriach Bony. Na kilku stronach wprawdzie przytacza różne fakty z jej życia (Beatillo, Historia di Bari 199-200, 201, 206207, 208-209), ale o tkaninach z Uczynkami miłosierdzia nie ma ani jednego słowa. Trudno w tej sytuacji odpowiedzieć na pytanie, skąd Cioffari pozyskał wspomnianą informację. Może znalazł ją w pracy innego autora albo pochodziła z archiwalnych źródeł, z których obficie korzystał? Do czasu odnalezienia źródła omawianej informacji nie można przyjąć podanej przez Cioffariego wiadomości, chociaż wydaje się całkiem prawdopodobna.

Sprawa okazała się jeszcze bardziej skomplikowana, gdy autorka niniejszego artykułu dotarła do innej pracy Beatilla, wydanej kilkanaście lat wcześniej (1620) Historia della vita, miracoli, traslatione, e gloria dell'illustrissimo confessore di Christo S. Nicolo il magno arcivescovo di Mira, w której znajduje się następująca wiadomość o tapiseriach Bony:

Quando poi verso il fine de'suoi giorni se ne venne Ella [Bona Sforza] à Bari suo materno Ducato, dove pochi mesi dopò l'arrivo, parti dalle miserie di questa vita, donò alla Chiesa istessa [San Nicolò] molte cose degne di lei; [...] quattro panni razzi, ne'quali sono lavorati con artificio amirabile le sette opere della misericordia. (Beatillo, Historia della vita 965)

Gdy później przy końcu swoich dni udała się ona [Bona Sforza] do Bari do swojego matczynego Księstwa, gdzie kilka miesięcy po przybyciu wpadła w poważne problemy życiowe, ofiarowała temu samemu Kościołowi [Świętego Mikołaja] wiele przedmiotów jej godnych; [...] cztery sztuki tapiserii, na których zostało wykonanych z mistrzostwem godnym podziwu siedem uczynków miłosierdzia. (Przekład A.B.) 
Wobec rozbieżności informacji trudno orzec, na którym etapie swojego życia królowa przekazała tapiserie do Bari. Zacytowany przekaz potwierdza jednak, że tkaniny zostały podarowane do bazyliki Świętego Mikołaja, a nie do katedry, jak podaje w swoim artykule Maria Hennel-Bernasikowa (Hennel-Bernasikowa 273). Beatillo nadmienia też, że Bona ofiarowała kościołowi cztery tapiserie. Nie mamy niestety żadnych informacji, co stało się z czterema pozostałymi należącymi do serii tkaninami. Może uległy zniszczeniu w czasie podróży lub podczas użytkowania w Polsce? Może też podarowała je komuś innemu?

O tapiseriach królowej, będących wówczas zapewne nadal w zbiorach bazyliki Świętego Mikołaja, pisze w wydanej 1685 r. książce Giovanni Battista Pacichelli. Podobnie jak Beatillo stwierdza, że Bona podarowała świątyni w ostatnich chwilach swego życia wiele cennych przedmiotów, w tym ,quttro arazzi, con le Sette Opere della Misericordia di meraviglioso lavoro” (Pacichelli 490), czyli „cztery tapiserie, z Siedmioma Uczynkami Miłosierdzia, cudownej roboty" (przekład A.B.).

Ostatnia odnaleziona informacja na temat omawianych tkanin znajduje się w książce Giuliego Petroniego, wydanej w 1858 r. Autor zacytował w niej fragment, jak pisze, odnalezionego starego dokumentu, który mówi o przekazaniu bazylice przez Bonę czterech tapiserii. Nie ma w nim niestety informacji, kiedy i przy jakiej okazji to się odbyło:

Donò alla Basilica $[\ldots]$ quatro panni d'arazzo, ne'quali erano rappresentate con artifizio ammirabile tutte le sette opere della Misericordia. (Petroni 621)

Podarowała Bazylice [...] cztery sztuki arrasów, które przedstawiały zachwycającą umiejętnością wykonania wszystkie siedem uczynków Miłosierdzia. (Przekład A.B.)

W podsumowaniu wszystkich dostępnych aktualnie informacji źródłowych można stwierdzić, że niewątpliwie cztery z ośmiu tapiserii z Uczynkami miłosierdzia, które były wykonane ze zwracającym uwagę mistrzostwem, Bona przekazała do bazyliki Świętego Mikołaja w Bari, zapewne uważając kościół za odpowiednie miejsce do ich przechowywania. Wybrała tę właśnie świątynię, gdyż - jak podkreśla to wielokrotnie Gerardo Cioffari (Cioffari, „Bona Sforza. Aspetti” 96, 98-99, 103-105; Cioffari, Bona Sforza. Donna 248-254, 259) - miała do tego świętego szczególne nabożeństwo. Nie można jednak jednoznacznie stwierdzić, kiedy nastąpiło przekazanie tkanin do bazyliki. Odbyło się ono na pewno między 1520 a 1557 r. Owe tapiserie znajdowały się $\mathrm{w}$ zbiorach świątyni jeszcze zapewne do końca XVII wieku. 
Przypuszczalnie ta seria, podobnie jak i cztery portiery Bony, do dzisiaj się nie zachowały.

Reasumując, należy nadmienić, że niestety w licznych publikacjach polskich i włoskich pojawia się nadal nieprawdziwa wiadomość, że przywiezione przez Bonę w jej wyprawie ślubnej tapiserie były pierwszymi w Polsce (Barycz, dostęp 5.11.2020). Jak wyżej wspomniano, nie można mieć wątpliwości, że przynajmniej kilka tego rodzaju tkanin nabył Zygmunt Stary jeszcze przed przyjazdem królowej do Krakowa. Prawdą jest to, co zauważyła Maria Hennel-Bernasik, że seria z Uczynkami miłosierdzia jest pierwszą na naszych ziemiach, o której wiemy, co przedstawiała. Na koniec trzeba podkreślić, co wynika z rozważań zawartych $\mathrm{w}$ niniejszym artykule, że pierwsze znane w Polsce portiery przywiozła z sobą w wyprawie ślubnej królowa Bona.

Ostatnia podsumowująca refleksja dotyczy faktu zainteresowania tapiseriami i ich nabywania przez ostatniego Jagiellona. W kontekście przeprowadzonych poszukiwań, mających na celu doprecyzowanie historii tapiserii przywiezionych przez jego matkę, warto zauważyć, że Zygmunt August jawi się jako przedstawiciel przynajmniej czwartego pokolenia dokonującego zakupu tych będących ówcześnie wyznacznikiem najwyższego statusu luksusowych tkanin. Przed nim czynili to jego rodzice oraz babka - Izabella Aragońska. Niestety dotąd nie udało się ustalić, czy znana ze znakomitego gustu i smaku w urządzaniu wnętrz Izabella kupowała, poza nabyciem na potrzeby posagu córki, także inne tapiserie. Wiadomo natomiast, że jeszcze wcześniej z wielkiego upodobania do tych kosztownych tkanin zasłynął pradziadek Zygmunta Augusta - Galeazzo Maria Sforza (Passera 320).

\section{BIBLIOGRAFIA}

\section{ŹRÓDŁA}

Beatillo, Antonio. Historia della vita, miracoli, traslatione, e gloria dell'illustrissimo confessore di Christo S. Nicolo il magno arcivescovo di Mira, Napoli, 1620 (reprint: Forgotten Books, 2018).

Beatillo, Antonio. Historia di Bari, principal città della Puglia nel Regno di Napoli. Napoli, 1637 (reprint: Cacucci, 2018).

Carmignano, Colantonio. Viaggio della Serenissima S. Bona Regina in Polonia, a cura di Andrea Colelli con una nota introduttiva di Luigi Marinelli, Lithos, 2018.

Pacichelli, Giovanni Battista. Memorie de'viaggi per l'Europa christiana, t. 1, Napoli, 1685.

Passero, Giuliano, Giuliano Passaro cittadino napoletano o sia prima pubblicazione in istampa, delle Storie in forma di Giornnali. Napoli, 1785. 


\section{OPRACOWANIA}

„Arazzo”. Dizionario italiano, www.grandidizionari.it/Dizionario_Italiano/parola/a/ arazzo.aspx? query=arazzo. Dostęp 5.11.2020

Barycz, Henryk. „Bona Sforza, regina di Polonia”. Dizionario Biografico degli Italiani, vol. 11 (1969). Treccani, www.treccani.it/enciclopedia/bona-sforza-regina-di-polonia_(DizionarioBiografico)/. Dostęp 5.11.2020

Bender, Agnieszka. Tapiserie w dawnej Rzeczypospolitej. Wydawnictwo KUL, 2004.

Bender, Agnieszka. „Bona Sforza d'Aragona i rola mody w kształtowaniu jej wizerunku”. Fabrica Litterarum Polono-Italica, nr 1 (2), 2020, ss. 33-52.

Bogucka, Maria. Bona Sforza, wyd. II, Ossolineum, 2004.

Botana, Federico. The Works of Mercy in Italian Medieval Art (c.1050-c.1400). Brepols, 2011.

Campbell, Thomas P., Maryan Wynn Ainsworth, Rotraud Bauer, Pascal-François Bertrand, Iain Buchanan, Elizabeth Cleland, Guy Delmarcel, Nello Forti Grazzini, Maria Hennel-Bernasikowa, Lorraine Karafel, Lucia Meoni, Cecilia Paredes, Hillie Smit, i Andrea Stockhammer. Tapestry in the Renaissance: Art and Magnificence. Metropolitan Museum of Art, 2002.

Chruszczyńska, Jadwiga, i Ewa Orlińska-Mianowska. Tkaniny dekoracyjne. Przewodnik dla kolekcjonerów. Arkady, 2009.

Cioffari, Gerardo. „Bona Sforza. Aspetti religiosi ed umanitari della sua personalità”. La regina Bona Sforza tra Puglia e Polonia: Atti del Convegno promosso dall'Associazione culturale Regina Bona Sforza sotto il patrocinio della Regione Puglia, della Provincia, del Comune e dell'Università di Bari: Bari, Castello Svevo, 27 aprile 1980, red. Bronisław Biliński i Jerzy Burchardt, Zakład Narodowy im. Ossolińskich, 1987, ss. 62-106.

Cioffari, Gerardo. Bona Sforza. Donna del Rinascimento. Tra Italia e Polonia. Levante, 2000.

Forti Grazzini, Nello. „Flemish Weavers in Italy in the Sixteen Century”. Flemish Tapestry Weavers Abroad. Emigration and the Founding of Manufactories in Europe: Proceedings of the International Conference, Mechelen, October 2-3, 2000, red. Guy Delmarcel, (Symbolae Series B, 27), Leuven University Press, 2002, ss. 131-161.

Genaille, Robert. Słownik malarstwa holenderskiego i flamandzkiego. Tłum. Ewa Maliszewska i Krystyna Secomska, Wydawnictwa Artystyczne i Filmowe, 1975, s. 134.

Ghidoli, Luigia Maria. „Arazzo”. Enciclopedia Italiana (1935). Treccani, www.treccani.it/enci clopedia/arazzo_\%28Enciclopedia-dell\%27-Arte-Medievale\%29/. Dostęp 5.11.2020.

Hennel-Bernasikowa, Maria. „Arrasy królowej Bony/Gli arazzi Della Regina Bona”. Bona Sforza. Regina di Polonia e duchesa di Bari. Catalogo della mostra. Parte 1, red. Maria Stella Calò Mariani i Giuseppe Dibenedetto, Nuova Comunicazione, 2000.

Malaguzzi Valeri, Francesco. La corte di Lodovico il Moro. Le arti industriali la letteratura la musica. U. Hoepli, 1923 (reprint: Forgotten Books, 2018).

Meijer, Emile. Les Trésors du Rijksmuseum Amsterdam. Edition Scala - Philip Wilson, 1985.

„Meester van de Levensbron”. RKD Images, rkd.nl/en/explore/images/record?query=acts+of+ mercy\&start=41 dostęp 5.11.2020.

„Meester van Sint Goedele”. RKD Images, rkd.nl/en/explore/images/record?query=acts + of + mercy \&start=84. Dostęp 5.11.2020.

Passera, Claudio. „Un incunabulo per lo sposalizio di Isabella d'Aragona: Le Nuptiae Illustrissimi Ducis Mediolani di Stefano Dolcino (1489)". Drammaturgia, t. 14, nr 4, 2017, ss. 305-326. 
Petroni, Giulio. Della storia di Bari dagli antichi tempi sino allo'anno 1856, t. 1, Napoli 1857 (reprint: Nabu Press, 2011).

„Regione siciliana assessorato dei beni culturali e dell'identitá siciliana”. Dipartimento Beni Culturali ed Ambientali e dell’Identitá Siciliana. Soprintendenza BB.CC.AA di Trapani FSC 20142020 „Patto per la Sicilia”, www.regione.sicilia.it/beniculturali/soprintp/SBCA_Trapani/ amministrazione_trasparente/11_doc_gare-contratti/2019_08_05_pubbl_avviso_manut_ straord_arazzi/relazione_tecnica_manut_straord_arazzi.pdf. Dostęp 5.11.2020.

Seremak, Waldemar. „Uczynki miłosierdzia”. Encyklopedia katolicka, t. 19, TN KUL, 2013, kol. 1284-1285.

„The Seven Works of Mercy: A Medieval Morality”. ReedDesign, reeddesign.co.uk/paintedchurch/ seven-works-of-mercy.htm. Dostęp 5.11.2020.

Tosi, Luigia Maria. „Portiera”. Enciclopedia Italiana (1935). Treccani, www.treccani.it/enciclo pedia/portiera_\%28Enciclopedia-Italiana\%29/. Dostęp 5.11.2020.

Van Bühren, Ralf. „Caravaggio's Seven Works of Mercy in Naples. The relevance of art history to cultural journalism". Church, Communication and Culture, t. 2, $\mathrm{nr}$ 1, 2017, ss. 63-87. doi: 10.1080/23753234.2017.1287283.

\section{TAPISERIE Z WYPRAWY ŚLUBNEJ KRÓLOWEJ BONY SFORZY D’ARAGONA}

\section{Streszczenie}

Królowa Bona Sforza, która przybyła w 1518 r. do Rzeczypospolitej z Bari, przywiozła godny posag, opisany przez Giuliano Passero. Wśród wielkiej liczby kosztownych przedmiotów znalazły się tapiserie - „panni di razza”: seria ośmiu z Uczynkami miłosierdzia i cztery portiery. Celem niniejszego artykułu jest uzupełnienie dotychczasowej wiedzy na ich temat, co stało się możliwe dzięki dotarciu do kilku wcześniej nieznanych polskiej literaturze przedmiotu źródeł i włoskich opracowań, oraz ich nowa interpretacja.

Opierając się na wszystkich dostępnych aktualnie informacjach z prac autorstwa Giuliano Passero, Colantonio Carmignano, Antonio Beatillo, Giovanni Battista Pacichelliego i Giulio Petroniego, można stwierdzić, że cztery z ośmiu tapiserii z Uczynkami miłosierdzia Bona przekazała między 1520 a 1557 r. do bazyliki Św. Mikołaja w Bari, gdyż szczególnie czciła jej patrona. Tapiserie te znajdowały się zapewne w świątyni jeszcze do końca XVII wieku. Przypuszczalnie tkaniny te do dzisiaj się nie zachowały.

Słowa kluczowe: Bona Sforza; tapiserie; Uczynki miłosierdzia; portiery; Kraków; Bari.

\section{TAPESTRIES FROM THE DOWRY \\ OF QUEEN BONA SFORZA D'ARAGONA}

S u m m a ry

Queen Bona Sforza d'Aragona, who came to the Kingdom of Poland from Bari in Italy in 1518, brought a handsome dowry, as described by Giuliano Passero. Among the large number of expensive items were tapestries - the "panni di razza", which was a series of eight tapestries portraying the Works of Mercy and four door curtains (portieres). The aim of this article is to 
supplement the current knowledge about these tapestries by drawing conclusions from studies by Italian authors on the subject matter and their new interpretations, which were previously unknown in Polish literature. Based upon all currently available source information, namely works by Giuliano Passero, Colantonio Carmignano, Antonio Beatillo, Giovanni Battista Pacichelli and Giulio Petroni, we can infer that Bona donated four of the eight tapestries from the Works of Mercy, which had been made with great mastery, to the Basilica of Saint Nicholas in Bari, probably because she considered the church to be a suitable place to preserve them. She also chose this particular church because she had a special devotion to its saint. The tapestries were placed in the basilica between 1520 and 1557. These fabrics were probably in the Bari church's collection until the end of the 17th century. Presumably, this series, as well as Bona's four portieres, have not survived to this day.

Key words: Bona Sforza; tapestries; Works of Mercy; door curtains (portieres); Kraków; Bari. 


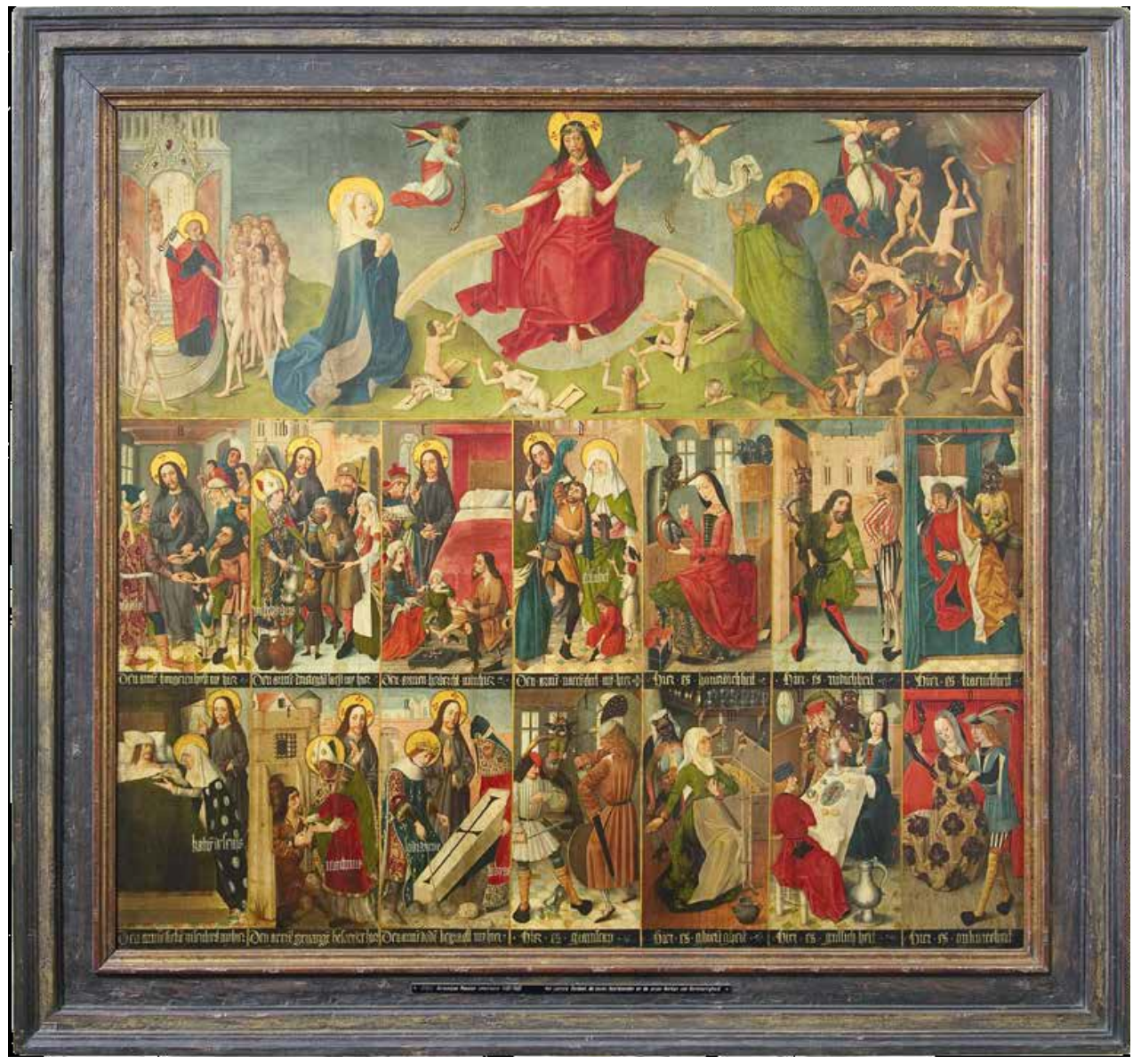

1. Sąd ostateczny i Uczynki miłosierdzia, nieznany malarz, między 1490 a 1500 r., (Maagdalenhuismuseum, Antwerpia),

wikimedia.org/wikipedia/commons/d/d4/15th_century-Unknown_Master_Maagdenhuis.jpg 


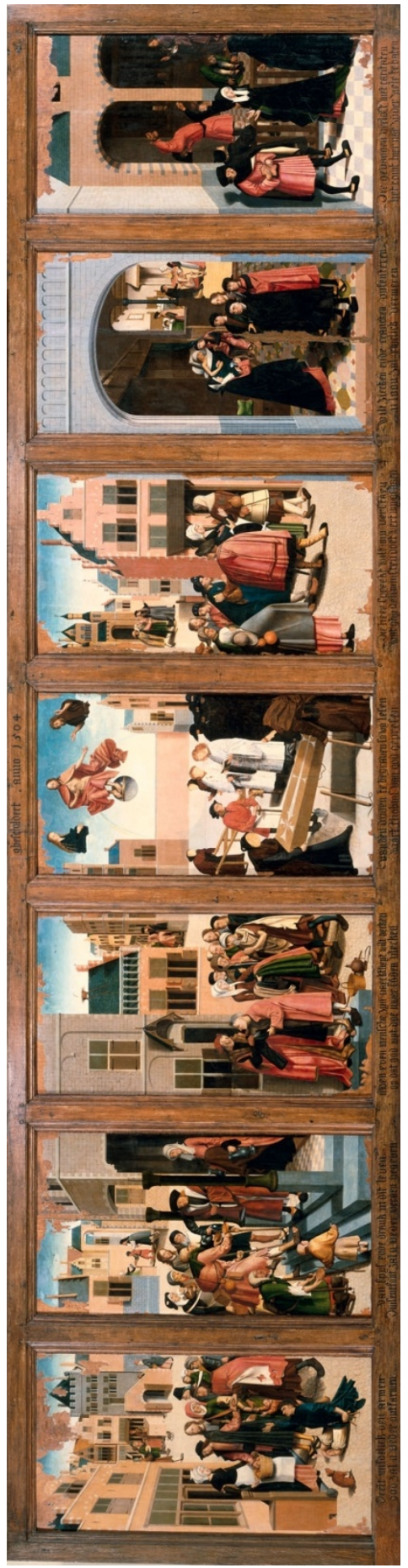

Uczynki miłosierdzia, Mistrz z Alkmaaru, 1504 r. (Rijksmuseum, Amsterdam).

wikimedia.org/wikipedia/commons/f/fd/Werken_van_B armhartigheid\%2C_Meester_van_Alkmaar_\%281504\% 29.jpg. Dostęp 20.03.2021. 